\title{
IPTEKS PERHITUNGAN PENYUSUTAN DENGAN METODE GARIS LURUS DAN SALDO MENURUN PADA ASET TETAP
}

\author{
Fitria Ayu Lestari Niu ${ }^{1}$, Novi Swandari Budiarso ${ }^{2}$ \\ ${ }^{1}$ Fakultas Ekonomi dan Bisnis Islam, Institut Agama Islam Negeri Manado, Jl. Dr. S. H. Sarundajang, \\ Kompleks Ringroad, Manado, 95128, Indonesia. \\ ${ }^{2}$ Program Studi Pendidikan Profesi Akuntansi, Fakultas Ekonomi dan Bisnis, Universitas Sam Ratulangi, Jl. \\ Kampus Bahu, Manado, 95115, Indonesia \\ E-mail: fitria.niu@iain-manado.ac.id
}

\begin{abstract}
Tax is a people's contribution to the state treasury based on law (which can be enforced) with no return. Tax planning is one form of tax management function in an effort to save tax legally, one of which is by choosing a method of depreciation that can support tax efficiency. The depreciation method permitted in taxation in Indonesia consists of two methods, namely the straight-line method and the declining balance method. Both of them were used in the calculation and recognition of depreciation expense have an impact on the smaller amount of net income generated resulting in a smaller tax burden borne by the taxpayer. The application of the straight-line method helps taxpayers save tax in the years the middle of the economic period while the declining balance method helps taxpayers save tax in the early years of reporting period. This means that both the straight-line method and the declining balance method have their advantages and disadvantages.
\end{abstract}

Keywords: depreciation; declining balance method; straight-line method

\section{PENDAHULUAN}

Setiap usaha atau bisnis yang dijalankan memiliki tujuan utama yaitu memperoleh keuntungan. Perusahaan membutuhkan sumber daya guna mencapai keuntungan yang diinginkan. Salah satu sumber daya tersebut adalah aset tetap sebagai aset operasional dalam kelangsungan usahanya. Manajemen aset tetap merupakan suatu pengelolaan yang rumit karena pihak manajemen perusahaan dihadapkan pada beberapa isu saat perolehan aset tetap seperti klasifikasi, metode penilaian dan pengukuran, pengawasan, penyusutan nilai dan dampak setiap keputusan terkait aset tetap tersebut terhadap Laporan Laba Rugi dan modal pemegang saham (Liapis \& Kantianis, 2015).

Aset yang diklasifikasikan sebagai aset tetap merupakan aset yang memiliki masa manfaat lebih dari satu tahun dan mengalami depresiasi (penyusutan) setiap tahun. Penyusutan aset tetap diakui oleh perusahaan sebagai beban yang akan mengurangi pendapatan dan mempengaruhi laba bersih yang akan dihasilkan (Goni \& Budiarso, 2018). Penyusutan mempengaruhi Laporan Laba Rugi dan Neraca dan digunakan dalam kontrak, pengungkapan pada pasar modal, pengambilan keputusan internal, pengawasan dan perhitungan pajak perusahaan (Keating \& Zimmerman, 1999). Dampak lain dari perhitungan beban penyusutan aset tetap oleh perusahaan adalah menjadi faktor pendorong kepatuhan wajib pajak dan implementasi salah satu sistem pemungutan pajak yaitu self-assessment (Mardiasmo, 2018:7; Ratnaningsih et al., 2014).

Penyusutan merupakan kategori ekonomi yang rumit karena menyangkut 2 (dua) elemen yaitu penyusutan sebagai elemen biaya dan penyusutan sebagai elemen kebijakan investasi yang mempengaruhi proses bisnis (Sigidov et al., 2016). Berdasarkan hal tersebut perusahaan perlu memperhatikan efisiensi pada pengeluaran beban-beban, perusahaan juga perlu memperhatikan penyusutan sebagai bagian dari kebijakan investasi perusahaan. Kedua 
elemen penyusutan memiliki kaitan erat dengan perusahaan selaku wajib pajak, yang memperoleh penghasilan dari aktivitas bisnisnya. Beban penyusutan aktiva tetap membutuhkan manajemen pajak agar beban pajak perusahaan menjadi efisien, terkait 2 (dua) alternatif metode penyusutan yang diperkenankan Undang-Undang Perpajakan yaitu metode garis lurus dan metode saldo menurun.

\section{TINJAUAN PUSTAKA}

Undang-Undang Nomor 28 Tahun 2007 Pasal 1 menyebutkan bahwa pajak adalah kontribusi wajib kepada negara yang terutang oleh orang pribadi atau badan yang bersifat memaksa berdasarkan Undang-Undang, dengan tidak mendapatkan imbalan secara langsung dan digunakan untuk keperluan negara. Menurut Mardiasmo (2018:1), pajak adalah iuran rakyat kepada kas negara berdasarkan Undang-Undang (yang dapat dipaksakan) dengan tidak mendapat imbalan kembali (kontraprestasi) yang langsung ditunjukan dan digunakan untuk membayar pengeluaran umum.

Perencanaan pajak merupakan salah satu bentuk dari fungsi manajemen pajak dalam upaya penghematan pajak secara legal. Menurut Suandy (2008:6), perencanaan pajak adalah langkah awal dalam manajemen pajak dimana dalam tahap ini dilakukan pengumpulan dan penelitian terhadap peraturan perpajakan dengan maksud dapat diseleksi jenis tindakan penghematan pajak yang dilakukan. Perencanaan pajak pada umumnya tertuju pada suatu proses untuk merekayasa usaha dan transaksi wajib pajak sehingga kewajiban pembayaran pajak berada dalam jumlah serendah mungkin tetapi masih dalam lingkup peraturan perpajakan. Perencanaan pajak pada umumnya tertuju pada suatu proses untuk merekayasa usaha dan transaksi wajib pajak sehingga kewajiban pembayaran pajak bisa efisien dalam lingkup peraturan perpajakan.

Salah satu bentuk penerapan perencanaan pajak yaitu pada pemilihan metode penyusutan dimana yang diperkenankan dalam perpajakan adalah metode garis lurus dan metode saldo menurun. Menurut Martani (2012:313), penyusutan adalah metode pengalokasian biaya tetap untuk menyusutkan nilai aset secara sistematis selama periode manfaat dari aset tersebut. Hal ini mengindikasikan bahwa penyusutan adalah suatu metode pengalokasian harga perolehan aset setelah dikurangi nilai sisa yang dialokasikan ke periodeperiode yang menerima manfaat dari aset tetap tersebut.

Pada metode garis lurus, perusahaan mengeluarkan biaya yang sama jumlah penyusutan untuk setiap tahun dari masa manfaat aset (Kieso et al., 2015:415). Metode ini menganggap bahwa aset tetap akan mengalirkan manfaat yang merata di sepanjang penggunaanya sehingga aset tetap dianggap akan mengalami tingkat penurunan fungsi yang sama besar disetiap periode penggunaan hingga aset tetap tidak dapat digunakan lagi (Baridwan, 2004:309). Metode ini adalah salah satu metode yang termasuk paling banyak diaplikasikan oleh perusahaan perusahaan di Indonesia.

Metode saldo menurun menghasilkan penurunan beban penyusutan tahunan selama masa manfaat aset. Metode ini disebut demikian karena depresiasi periodik didasarkan pada penurunan nilai buku aset. Dengan metode ini, perusahaan menghitung beban penyusutan tahunan dengan mengalikan nilai buku di awal tahun dengan tingkat depresiasi saldo menurun. Tingkat depresiasi tetap konstan dari tahun ke tahun, tetapi nilai buku yang tarifnya penurunan diterapkan setiap tahun (Kieso et al., 2015:417). Pada metode ini, aset tetap diasumsikan memberikan manfaat terbesarnya pada periode awal masa penggunaan, dan akan mengalami penurunan fungsi yang makin besar di periode-periode berikutnya seiring umur ekonomis aset tetap yang berkurang. Jadi semakin lama penggunaan aset tetap maka kontribusinya akan menurun dalam operasional perusahaan. 


\section{METODE DAN TEKNIK PENERAPAN IPTEKS}

\subsection{Metode penerapan ipteks}

Penerapan ipteks ini dalam bentuk perhitungan metode penyusutan pada aset tetap yang diperkenankan dalam perpajakan di Indonesia yaitu dengan menggunakan metode garis lurus dan metode saldo menurun.

\subsection{Teknik penerapan ipteks}

Teknik yang dipilih dalam penerapan ipteks ini adalah menghitung perencanaan pajak dari segi penggunaan metode penyusutan pada aset tetap yang terdiri dari metode garis lurus (MGL) dan metode saldo menurun (MSM) dengan rumus berikut.

$$
\begin{aligned}
\text { MGL } & =\frac{\text { Harga Perolehan }- \text { Nilai Residu }}{\text { Umur Ekonomis Aset Tetap }} \\
\text { MSM } & =[(100 \%: \text { Umur Ekonomis } \mathrm{x} \text { 2] } \times \text { Harga Perolehan }
\end{aligned}
$$

\section{PEMBAHASAN}

\subsection{Gambaran objek penerapan ipteks}

Objek dalam penerapan ipteks ini adalah badan usaha yang memiliki aset tetap dan mengakui pengurangan masa manfaat aset tersebut sebagai beban penyusutan yang mengurangi pendapatan yang berdampak pada laba perusahaan. Penentuan kelompok aset dan tarif penyusutan harta berwujud sesuai diatur dalam Undang-Undang Nomor 36 Tahun 2008 Pasal 11 tentang Pajak Penghasilan dengan uraian sebagai berikut.

1. Penyusutan atas pengeluaran untuk pembelian, pendirian, penambahan, perbaikan, atau perubahan harta berwujud, kecuali tanah yang berstatus hak milik, hak guna bangunan, hak guna usaha, dan hak pakai, yang dimiliki dan digunakan untuk mendapatkan, menagih, dan memelihara penghasilan yang mempunyai masa manfaat lebih dari 1 (satu) tahun.

2. Penyusutan atas pengeluaran harta berwujud sebagaimana dimaksud pada ayat (1) selain bangunan, dapat juga dilakukan dalam bagian-bagian yang menurun selama masa manfaat, yang dihitung dengan cara menerapkan tarif penyusutan atas nilai sisa buku, dan pada akhir masa manfaat nilai sisa buku disusutkan sekaligus, dengan syarat dilakukan secara taat asas.

3. Penyusutan dimulai pada bulan dilakukannya pengeluaran, kecuali untuk harta yang masih dalam proses pengerjaan, penyusutannya dimulai pada bulan selesainya pengerjaan harta tersebut.

4. Untuk menghitung penyusutan, masa manfaat dan tarif penyusutan harta berwujud ditetapkan seperti yang tercantum dalam Tabel 1.

Tabel 1. Kelompok masa manfaat dan tarif penyusutan harta berwujud sesuai dengan Undang- Undang

\begin{tabular}{|c|c|c|c|c|}
\hline & \multirow[t]{2}{*}{ Kelompok Harta Berwujud } & \multirow[t]{2}{*}{ Masa Manfaat } & \multicolumn{2}{|c|}{$\begin{array}{c}\text { Tarif Penyusutan Sebagaimana } \\
\text { Dimaksud Dalam }\end{array}$} \\
\hline & & & Ayat (1) & Ayat (2) \\
\hline \multirow[t]{5}{*}{$\mathrm{I}$} & Bukan Bangunan & & & \\
\hline & Kelompok 1 & 4 Tahun & $25 \%$ & $50 \%$ \\
\hline & Kelompok 2 & 8 Tahun & $12,5 \%$ & $25 \%$ \\
\hline & Kelompok 3 & 16 Tahun & $6,25 \%$ & $12,5 \%$ \\
\hline & Kelompok 4 & 20 Tahun & $5 \%$ & $10 \%$ \\
\hline \multirow[t]{3}{*}{ II } & Bangunan & & & \\
\hline & Permanen & 20 Tahun & $5 \%$ & \\
\hline & Tidak Permanen & 10 Tahun & $10 \%$ & \\
\hline
\end{tabular}
Pajak Penghasilan nomor 36 tahun 2008 pasal 11 ayat (6) 


\subsection{Pembahasan}

Perpajakan hanya mengizinkan penggunaan dua jenis metode penyusutan yaitu metode garis lurus dan metode saldo menurun dalam melakukan penyusutan aset tetap. Tabel 2 menyajikan simulasi penghitungan biaya penyusutan atas aset tetap. Diasumsikan data aset tetap berupa mesin pada sebuah perusahaan pembuat roti adalah seharga IDR 200.000.000 yang dibeli pada tanggal 1 Januari 2011 dengan masa manfaat fiskal selama 8 tahun. Tabel 2 menyajikan penghitungan metode penyusutan menurut MGL dan MSM dan perbedaan hasil atas penerapan kedua metode penyusutan tersebut.

Tabel 2. Perhitungan biaya penyusutan metode garis lurus dan saldo menurun

\begin{tabular}{ccrlrr}
\hline \multicolumn{3}{c}{ Penyusutan Fiskal } & \multicolumn{3}{c}{ Efisiensi PPh (25\%) } \\
\hline Tahun & MGL & \multicolumn{1}{c}{ MSM } & MGL & \multicolumn{1}{c}{ MSM } & \multicolumn{1}{c}{ Perbedaan } \\
\hline 2011 & 25.000 .000 & 50.000 .000 & 6.250 .000 & 12.500 .000 & 6.250 .000 \\
2012 & 25.000 .000 & 37.500 .000 & 6.250 .000 & 9.375 .000 & 3.125 .000 \\
2013 & 25.000 .000 & 28.125 .000 & 6.250 .000 & 7.031 .250 & 781.250 \\
2014 & 25.000 .000 & 21.093 .750 & 6.250 .000 & 5.273 .437 & -976.563 \\
2015 & 25.000 .000 & 15.820 .313 & 6.250 .000 & 3.955 .078 & -2.294 .922 \\
2016 & 25.000 .000 & 11.865 .235 & 6.250 .000 & 2.966 .309 & -3.283 .691 \\
2017 & 25.000 .000 & 8.898 .926 & 6.250 .000 & 2.224 .731 & -4.025 .269 \\
2018 & 25.000 .000 & 26.696 .776 & 6.250 .000 & 6.674 .194 & 424.194 \\
\hline
\end{tabular}

Catatan: MGL adalah Metode Garis Lurus, MSM adalah Metode Saldo Menurun, dan perbedaan adalah selisih antara MSM dan MGL.

Tabel 2 menyajikan hasil perhitungan menggunakan metode garis lurus dan metode saldo menurun beserta selisih perbandingan efisiensi pajak dari kedua metode tersebut. Hasil penghitungan menunjukkan bahwa penyusutan dengan menggunakan metode garis lurus setiap tahun memiliki saldo yang bersifat tetap atau tidak berubah, sedangkan penyusutan dengan menggunakan metode saldo menurun memiliki saldo penyusutan tidak bersifat tetap atau berubah-ubah setiap tahunnya. Jika penyusutan dari kedua metode tersebut dibandingkan maka tahun pertama memiliki selisih sebesar IDR 6.250.000, tahun kedua memiliki selisih sebesar IDR 3.125.000, tahun ketiga memiliki selisih sebesar IDR 781.250, dan tahun kedelapan memiliki selisih sebesar IDR 424.194 sehingga beban penyusutan yang diakui adalah lebih besar apabila menggunakan metode saldo menurun dibandingkan menggunakan metode garis lurus. Namun pada tahun keempat sampai tahun ketujuh justru penyusutan dengan menggunakan metode garis lurus lebih efisien dibanding metode saldo menurun.

Perbandingan tersebut menunjukkan bahwa baik metode garis lurus maupun metode saldo menurun yang memiliki saldo lebih besar dari kedua metode tersebut berdampak pada lebih kecilnya jumlah laba bersih yang dihasilkan yang mengakibatkan lebih kecilnya beban pajak yang ditanggung oleh wajib pajak. Penggunaan metode saldo menurun membantu wajib pajak dalam menghemat pajak di tahun-tahun awal (Abdelkader et al., 2018) sedangkan metode garis lurus membantu wajib pajak dalam menghemat pajak di tahun-tahun tengah masa penyusutan. Hal ini berarti bahwa baik metode garis lurus maupun saldo menurun, keduanya sama-sama memiliki kelebihan dan kekurangannya masing-masing. Ketika wajib pajak telah memilih salah satu dari kedua metode tersebut dalam menghitung dan mengakui beban penyusutannya di awal tahun penyusutan maka wajib pajak tersebut harus konsisten dengan pilihannya sampai akhir tahun penyusutan. 


\section{KESIMPULAN DAN SARAN}

\subsection{Kesimpulan}

Perencanaan pajak merupakan salah satu bentuk dari fungsi manajemen pajak dalam upaya penghematan pajak secara legal salah satunya dengan memilih metode penyusutan aset tetap yang dapat menunjang efisiensi pajak. Metode penyusutan yang diperkenankan dalam perpajakan di Indonesia terdiri dari dua metode yaitu metode garis lurus dan metode saldo menurun. Baik metode garis lurus maupun metode saldo menurun yang memiliki saldo lebih besar dari kedua metode tersebut berdampak pada lebih kecilnya jumlah laba bersih yang dihasilkan yang mengakibatkan lebih kecilnya beban pajak yang ditanggung oleh wajib pajak. Penerapan metode garis lurus membantu wajib pajak dalam menghemat pajak di tahun-tahun tengah masa ekonomis sedangkan metode saldo menurun membantu wajib pajak dalam menghemat pajak di tahun-tahun awal pelaporan laba rugi. Hal ini berarti bahwa baik metode garis lurus maupun saldo menurun, keduanya sama-sama memiliki kelebihan dan kekurangannya masing-masing.

\subsection{Saran}

Wajib pajak atau badan usaha yang akan melakukan perencanaan pajak dengan langkah pemilihan metode penyusutan harus dapat mempertimbangkan metode apa yang akan dipilih untuk diterapkan dalam pengakuan penyusutannya. Perlu evaluasi dari data pada tahun-tahun sebelumnya dalam menetapkan metode yang akan digunakan sebab wajib pajak harus konsisten dengan pilihannya dari awal sampai akhir tahun pelaporannya.

\section{DAFTAR PUSTAKA}

Abdelkader, B., Sofiane, Mostéfaoui, S., \& Zaineb, S. (2018). Taxation effect on depreciation: Evidence from the Algerian tax system. European Journal of Business Management 10(9). 85-89. https://www.iiste.org/Journals/index.php/EJBM/article/view/41483

Mardiasmo. (2018). Perpajakan. Edisi revisi tahun 2018. Yogyakarta: Andi.

Martani, D. (2012). Akuntansi keuangan menengah berbasis PSAK. Jakarta: Salemba Empat

Goni, Y. M. F. \& Budiarso, N. S. (2018). Analysis calculation of depreciation fixed assets according to financial accounting standards and tax laws as well as impact on taxable income in PT. Massindo Sinar Pratama Manado. Jurnal Accountability, 7(1). https://doi.org/10.32400/ja.19072.7.01.2018.11-20.

Keating, A. S., \& Zimmerman, J. L. (1999). Depreciation-policy changes: Tax, earnings management, and investment opportunity incentives. Journal of Accounting and Economics, 28(3), 359-389. https://doi.org/10.1016/S0165-4101(00)00004-5.

Kieso, D. E, Kimmel, P. D., \& Weygandt, J. J. (2015) Financial Accounting, $2^{\text {nd }}$ Edition. New Jersey: John Wiley \& Sons, Inc.

Liapis, K. J., \& Kantianis, D. D. (2015). Depreciation methods and Life Cycle Costing (LCC) methodology. Procedia Economics and Finance, 19, 314-324. https://www.sciencedirect.com/science/article/pii/S2212567115000325

Baridwan, Z. (2004). Intermediate Accounting, Edisi 8. Yogyakarta: BPFE.

Peterson, R. H. (2002). Accounting for fixed assets, $2^{\text {nd }}$ Edition. New York: John Wiley and Sons, Inc.

Ratnaningsih, S. D. A., Endah, S. M. D., M. A. Ariee., \& Indarto, S. L. (2014). Improving Technology Acceptance Model (TAM) for the new fixed assets Indonesian tax accounting systems. South East Asia Journal of Contemporary Business, Economics and Law,5(1). 30-37. https://seajbel.com/wp-content/uploads/2014/12/ACC-18- 
Improving-Technology-Acceptance-Model-TAM-for-The-New-Fixed-AssetsIndonesian-Tax-Accounting.pdf

Republik Indonesia. (2007). Undang-Undang Nomor 28 Tahun 2007 Pasal 1 tentang Ketentuan Umum dan Tata Cara Perpajakan. Jakarta.

Republik Indonesia. (2008). Undang-Undang Nomor 36 Tahun 2008 Pasal 11 tentang Pajak Penghasilan. Jakarta.

Sigidov, Y. I., Rybyantseva, M. S., \& Adamenko, A. A., \& Yarushkina. E. A. (2016). Methodological aspects of depreciation as an economic category. International Journal of Economics and Financial Issues, 6(S1). 88-95. https://www.econjournals.com/index.php/ijefi/issue/view/76.

Suandy, E. (2008). Hukum Pajak, Edisi 2. Jakarta: Salemba Empat. 